\title{
Application of Task-Based Approach in College English Teaching Based on Internet-assisted Multimedia
}

\author{
a JIANG Ling, 'sUN Kai \\ ${ }^{a}$ Public English Department Harbin Normal University Harbin, P.R. China \\ ${ }^{b}$ School of Management Harbin University of Science and Technology Harbin, P.R. China
}

\begin{abstract}
College English teaching in China is an essential part of the whole education system, but there have been some problems that students have been undergoing with low efficiency and instrumental motivation, and that their language input is confined in what teachers taught. In order to solve the problems, this article designs a test and collects data to check the effectiveness of the task-based approach within the Internet-assisted multimedia in college English teaching. The results show that Linguistic form was analyzed and practiced with task-based approach which may help the learners notice the linguistic problems and try out new language forms and structures, and that Internet-assisted multimedia has been effective in intriguing learners' interests and greatly enhanced their self-esteem.
\end{abstract}

Index Terms: Internet-assisted multimedia; task-based approach; college English teaching

(C) 2012 Published by MECS Publisher. Selection and/or peer review under responsibility of the International Conference on E-Business System and Education Technology

\section{Introduction}

Chinese English teachers are practicing different teaching models with the increasing importance of English in the $21^{\text {st }}$ century. College English teaching, as an essential and fundamental part of the education system, has been undergoing with low efficiency even though teachers have made great effort to improve it. College students, who have studied English for many years, cannot "function" properly in social contexts, so College English teaching reform is imperative.

As an innovative approach, task-based approach (TBA) has become more and more prevalent among the English teaching modes; however, there are still many problems, for example, teachers still act as controllers in classrooms, and tasks in classrooms are language drills or practice. In fact, there is seldom communication in classroom, and learners are still passive receivers. Hence, we need to solve the problems by using some new and effective ways to teach. It is beyond doubt that computers and the internet can add enormous potential to language teaching and learning, if teachers and learners know how to make use of the technology. But computerassisted teaching is still neglected by most college English teachers in China. They either regard it as a waste of time or treat it as a game. In order to fill in the gap of the existing problems in teaching and learning the second 
language, we need to combine the two factors and conduct research of the theory of constructivism to find a more efficient teaching approach.

\section{Literature Review}

\subsection{The History and the Theoretical Basis of the Task-based Approach}

Task-based Approach is the latest development results of western English education and also the latest development of the communicative approach, laying stress on learning by doing. Prabhu (1987) firstly advocated that "structure can best be learned when attention is focused on meaning" and "adopts meaning-focused activities" [1]. As the key to TBL approach, the term "task" has been defined in a variety of ways. Task is a piece of work undertaken for oneself or for others, freely or for some reward (Long, 1985) [2]. Nunan (1989) divided classroom tasks into real-world task and pedagogical task [3]. Willis (1996) identified six main types of tasks, including listing, ordering and sorting, comparing, problem solving, sharing personal experiences and creative task [4]. Form the pedagogical perspective, Richard (2000) stressed on language knowledge [5]. From the perspective of language learning, Breen (1987) claimed that a task is a basic unit for designing language classroom activity [6]. Most methods are heavily rooted in linguistic theories, theories of learning or theoretical assumptions on the nature of linguistic communication. Vygotsky (1962) thought of language as a social event, a shared social activity within a community [7]. The interaction belongs to the very nature of Language. The functional nature of language is highlighted by Firthian and Hallidayan linguistics. Wilkins (1976) incorporated this functional dimension into methodological issues on language teaching [8]. From that point of view Wilkins' notional-functional syllabus is more synthetic than analytical, as Long and Crookes (1993) claimed [9]. In the process of language acquisition the role of the learner is central and decisive, but it takes place only if knowledge (language) is integrated by the individual into his own set of values and idiosyncrasy and if a linguistic system is built.

\subsection{An Overview of the Internet-assisted Multimedia Language Teaching and its Theoretical Basis}

\section{1)The History of the Internet-assisted Multimedia Language Teaching}

Computer-Assisted English Language Teaching and Learning (CALL) has mature guidance theories developed by both foreign and domestic scholars for few decades. The present research, which is mainly descriptive in nature, is intended to investigate how learners have been influenced by CALL in the light of motivation, learner autonomy, learning strategies and interactive and cooperative learning.

According to Warschauer and Healey (1998), the development of the CALL underwent three periods [10]. In the 1960's and 1970's the first form of computer-assisted language teaching and learning featured repetitive language drill, the so-called drill-and-practice method. The computer used to be viewed as little more than a mechanical tutor that never feel tired of extensive drill, explicit grammar instruction and translation tests. The communicative CALL emerged in the 1970's and 1980's as a reaction to the behaviorist approach to language learning. This form of computer-based instruction corresponded to cognitive theories which recognized that learning was a creative process of discovery, expression, and development. Another stage of computer-assisted language learning is integrative CALL. Integrative CALL seeks both to integrate the various skills of language learning and to integrate technology more fully into language teaching. So the multimedia-networked computer provides a range of informational, communicative and publishing tools that are potentially available to every student. Table I shows the characteristics of the three phases of CALL. 
TABLE I. THREE PHRASES OF CALL

\begin{tabular}{|c|c|c|c|}
\hline & $\begin{array}{c}\text { Behaviorist } \\
\text { CALL }\end{array}$ & $\begin{array}{c}\text { Communicative } \\
\text { CALL }\end{array}$ & $\begin{array}{c}\text { Integrative } \\
\text { CALL }\end{array}$ \\
\hline $\begin{array}{l}\text { Learning } \\
\text { Theory }\end{array}$ & Behaviorism & $\begin{array}{l}\text { Information- } \\
\text { processing } \\
\text { and } \\
\text { Constructivism } \\
\end{array}$ & $\begin{array}{c}\text { Social } \\
\text { constructivism }\end{array}$ \\
\hline Computers & $\begin{array}{l}\text { Mainframe } \\
\text { computers }\end{array}$ & Microcomputers & $\begin{array}{l}\text { Computers } \\
\text { and } \\
\text { the Internet }\end{array}$ \\
\hline $\begin{array}{l}\text { Linguistic } \\
\text { Theory }\end{array}$ & Structuralism & $\begin{array}{c}\text { Transformational } \\
\text { generative } \\
\text { grammar }\end{array}$ & $\begin{array}{c}\text { A more } \\
\text { semantic } \\
\text { and more } \\
\text { social } \\
\text { view of } \\
\text { language }\end{array}$ \\
\hline $\begin{array}{l}\text { Teaching } \\
\text { Approach }\end{array}$ & Audiolingualism & $\begin{array}{c}\text { Communicative } \\
\text { language } \\
\text { teaching }\end{array}$ & Task-based \\
\hline
\end{tabular}

The participation of the Internet in modern foreign language teaching has brought great changes to teaching concepts, teaching models, teaching methods and means, and to a still wider range of language teaching and language learning materials. It's a great influence and the challenge should be fully realized and met.

2)The importance of the Internet-assisted Multimedia Language Teaching

Computer technology has been used in education for more than forty years. The popularization of modem multimedia personal computers provides technological assurance for the progress of foreign language teaching. And the Internet not only offers greatly expanded opportunities for language learners to communicate with native speakers or others promptly and inexpensively; but also offers access to the most update and abundant information throughout the world. Many CALL educators place greater emphasis on language use in authentic social contexts and integrate various language skills and computers more fully into language learning process. In a CALL EFL classroom, the role of technology is to support, enhance and facilitate the learning process. Debski (1997) proclaims that it is used to enrich the language classroom through fostering human to human communication and creative endeavor, and build environments in which learners could learn through exploration and experience[11]. In a network environment, students are given much independence and responsibility for their own study. The teacher's main role is to explain objectives, introduce materials and procedures, and monitor the learning process. Thus, in network-based learning, students have a great control over their learning while the teacher is a kind of facilitator. This is the ideal learning environment.

\section{Analysis of the Present Situation of Foreign Language Teaching and Learning}

\section{1 The Present Situation of the TBL in China}

In China, Xia (1998) et al, at Zhongshan University, initially did the research on TBL [12]. They introduced and analyzed the essence of TBL, believing TBL means that language teaching should be closely related to the real word and classroom teaching reflects society. Language learning should not be only language practice but method learning. The goal of the language teaching is not only to learn language but to develop the students' cognitive ability with the means of the language. Meanwhile, Zhang (1998) analyzes the theoretical bases, the scope and the advantages and disadvantages of TBL Syllabus [13]. In 2000, Cheng pointed out TBL syllabus should combine the process syllabus with tasks in China [14]. 
In 2001, TBL was put forward by Educational Commission to challenge the traditional language teaching. TBL began to be widely used and developed greatly in primary and secondary school. But problems still existed, such as the task in every class takes the same model or the task-based teaching means learning by students themselves. If learning is stressed and doing is looked over, learning will be only for learning's sake. That is the traditional teaching model. On the other hand, if doing is stressed and learning is ignored, doing will be only for doing's sake, which still cannot be called the task-based teaching. Besides, how to practice task-based approach to College English teaching has seldom been discussed so far.

\section{2 Analysis of the Present Situation of the Application of the Internet-assisted Multimedia}

Microsoft Word, Microsoft PowerPoint and Microsoft Front-page are the most frequently used courseware developers. In a CALL classroom, teachers will use computer to replace old-fashioned chalk and blackboard. More active, sometimes even interactive courseware will be presented to learners. Unquestionably, to learners, it is more vivid and interesting to use the highlighted key points and flickering mouse arrow to support traditional teaching. At present, due to its convenience and adaptability to both single computer and the Internet, more and more teachers choose to develop web page courseware. Thus learners can jump to any page they want to read. Language learners may also increase their interests through use of combined media. For example, use of video or animation, supported by subtitles, with instantly available definition language items, and by on-line tasks with synchronous feedback may motivate learners to attend class because such learning supports may make the input more comprehensible. These learning supports may also motivate some learners to "notice”, and consequently increase their awareness of the linguistic features of the input instead of the grammar points, and to put it into practice as more as possible.

\section{3 Problems in Applying a Task-based Approach in Chinese Educational Context}

Lots of students learn English just because English is a compulsory subject. Getting a good mark is the most important consideration for students. Very few students enjoy English for the reason they want to integrate into the culture of its speaker. It is not difficult to find that the students in those schools are not highly motivated, for their motivation is instrumental, not integrative. The second obstacle is the teachers who are non-native speakers. Their low level of academic in language teaching may reflect this deficiency. As Willis (1996) said that "the exposure and input come from teacher talk, especially during the pre-task phase and when reviewing language analysis” a demand on the teachers and makes most of them. Obviously this makes feel frustrated. Except for this, the teachers are supposed to control practice and make sure that as many learners as possible participate in the class.

In order to overcome the current problems of English language teaching in China, TBL seems to be a promising path to pursue. The reasons are that it is premised on the theoretical view that instruction needs to be compatible with the cognitive processes which was ignored by the traditional Grammar-Translation Approach, that teachers can keep up with developments in English teaching methods outside China by introducing TBA, and that TBL can create more ideal situations for language learning within the Chinese context. According to Kasper (2005), real-world materials which are introduced in task-based classrooms, can foster students' pragmatic competence, especially regarding cultural reflections.

\section{Research Design}

\section{1 Study Aim}

The study is designed to check the effectiveness of the task-based approach within the Internet-assisted multimedia in the process of teaching the College English. It is hypothesized that task-based approach through Internet-assisted multimedia can function positively in reforming the teaching and learning situation in China's college English teaching and learning. 


\section{2 Subjects and Procedures}

The author has chosen 100 freshmen of different departments in Harbin Normal University with similar scores of entrance exam and divided them into two classes equally. Class 1(experimental group) have undertaken an “ $3+1+x$ ” teaching model, which still requires the students to learn automatically by using the campus-wide language learning platform after class besides the 3 classes of the intensive reading and 1 class of listening,; Class 2 (unexperimental group) have attended in regular lessons. The study was conducted in the winter and summer semesters between 2009 and 2010. The students of Class 1 learn with Internet-assisted multimedia once in a week for free, two class hours for each time. Besides, they regularly have learned the materials provided by the Campus-wide Language Learning Platform several times for self studying in the lab. During this learning process, teacher used different ways to facilitate learner motivation, encouraged autonomous learning and interaction \& cooperation between learners, and trained them in basic knowledge of learning strategies. In order to test the efficiency of the TBL within the context of we collected the two term-examination data. At the end of the second term, in order to find out our students' general attitudes toward the new approach use, several question items were designed to elicit the subjects' responses.

\section{Data Analysis and Discussion}

This study was implemented to determine the effects of combining Task Based Approach with the Internetassisted Multimedia on learners' learning proficiency. The final results on the subject-two classes of Harbin Normal University will be analyzed, and discussions are presented on the statistical results.

\section{1 Test Score Analysis and Discussion}

\section{1)Test Score Analysis}

The results for the comparison of the final scores of the two groups (experimental vs. unexperimental) are presented in Table II as following:

TABLE II. THE FINAL SCORE IN TWO TERMS

\begin{tabular}{|c|c|c|c|c|}
\hline \multicolumn{3}{|c|}{ Class 1 } & \multicolumn{2}{c|}{ Class 2 } \\
\hline & mean & $\begin{array}{c}\text { Standard } \\
\text { deviation }\end{array}$ & mean & $\begin{array}{c}\text { Standard } \\
\text { deviation }\end{array}$ \\
\hline First term & 68.38 & 9.45 & 65.7 & 7.92 \\
\hline $\begin{array}{c}\text { Second } \\
\text { term }\end{array}$ & 84.9 & 4.22 & 78.6 & 7.86 \\
\hline
\end{tabular}

As mentioned above, Class 1 and the Class 2 were at the same level at the beginning of the research. However, in the first term, Class 1 scored a little better than Class 2 but no significant difference could be found from the mean score (68.38 V.S. 65.7). But in the second term, Class 1 scored significantly better than Class 2. (84.9 V.S.78.6). From standard deviation, we come to the conclusion that during short-term CALL instruction, TBL lessons were effective only to some of the students (Class1 standard deviation $=9.45$, Class 2 standard deviation =7.92). But in the long run, things changed greatly. After a year of CALL instruction, significant difference in scores was consumedly shortened. The highest score of the student in the two classes (individual student highest score in class $1=93$, class $2=90$ ) shows that TBL lessons with CALL components are beneficial with those high achieving students. The lowest score of the individual student in Class 1 was 77, but that of Class 2 was only 60, there is great difference here, this testified that TBL lessons within the context of CALL is more beneficial with lower-achieving students than with higher-achieving ones. On the whole, from the two terms results, we may definitely come to the conclusion that the application of task-based approach is more effective than traditional teacher-directed approach within the context of CALL. 


\section{2)Discussion}

In order to accomplish the tasks, the learners in the experimental group cooperated with each other and turned out meaningful production. Interactive and positive learning was achieved. The learners were fully exposed to authentic input and output, which contributed a lot to the intake of the target language and to modify their interlanguages. The learners in the conventional class had no chances to explore the language and to check their hypothesis about the language; the input was only the textbooks and the formal instruction from the teacher. Then they could not study efficiently, thus improved slowly.

\section{2 Analysis of the Questionnaire for the Students}

The questionnaire, was arranged in the following angles: learner's motivation, autonomy, learning strategies, and interactive\& cooperative learning, etc. They were purposefully arranged in a random order. Nine questions are answered on a five-point scale which is strongly disagree, disagree, neutral, agree and strongly agree. The questions and their findings are shown in Table III.

TABLE III. THE SUMMARY OF THE QUESTIONNAIRE DATA FOR STUDENTS USE

\begin{tabular}{|c|c|}
\hline Questions & Finding \\
\hline $\begin{array}{l}\text { 1. I feel more confident and comfortable to join } \\
\text { discussion via computer. }\end{array}$ & $\begin{array}{l}\text { About } 65 \% \text { of the students agree with this opinion, } \\
\text { that is, the computer has become one part of their life. }\end{array}$ \\
\hline $\begin{array}{l}\text { 2. I enjoy using Internet to communicate in English } \\
\text { with people around the world. }\end{array}$ & $\begin{array}{l}\text { About } 69 \% \text { of the students chose "agree" or "strongly } \\
\text { agree". }\end{array}$ \\
\hline $\begin{array}{l}\text { 3. The way of learning "College English" course in } \\
\text { CALL environment has increased my interest in } \\
\text { communicating in English. }\end{array}$ & $\begin{array}{l}\text { About } 70 \% \text { of the students felt it was very interesting } \\
\text { to use computer to learn English. }\end{array}$ \\
\hline $\begin{array}{l}\text { 4. The courseware my teacher has used helps me } \\
\text { understand the text better. }\end{array}$ & $\begin{array}{l}\text { About } 69 \% \text { of the students chose "agree" or "strongly } \\
\text { agree", that is, in their opinion; the courseware the } \\
\text { teacher used has helped them a lot. }\end{array}$ \\
\hline $\begin{array}{l}\text { 5. I've taken more responsibility for my own learning } \\
\text { in the Internet Classroom. }\end{array}$ & $\begin{array}{l}\text { About } 69 \% \text { of the students believed that it is them } \\
\text { who are the key role of the study activity, and thanks } \\
\text { to the Internet, they can be their own master. They are } \\
\text { more and more independent than before. }\end{array}$ \\
\hline $\begin{array}{l}\text { 6. I can choose what is suitable to my own English } \\
\text { level to learn on the Internet. }\end{array}$ & $\begin{array}{l}\text { About } 75 \% \text { of the students chose "neutral" or "agree" } \\
\text { as their answers, which means that they are quite clear } \\
\text { about their present learning situation. }\end{array}$ \\
\hline $\begin{array}{l}\text { 7. When I meet problems in my English learning, I' } \\
\text { d like to find solutions on the Internet by myself as } \\
\text { soon as possible. }\end{array}$ & $\begin{array}{l}\text { About } 65 \% \text { of the students agree with this opinion, } \\
\text { that is, the computer has become one part of their life. }\end{array}$ \\
\hline $\begin{array}{l}\text { 8. Information can be better processed by computers, I } \\
\text { can choose what I want and acquire information as } \\
\text { much as possible in the shortest time. }\end{array}$ & $\begin{array}{l}\text { About } 79 \% \text { of the students chose "agree" or } \\
\text { "strongly agree" for this statement. It implies that } \\
\text { they are quite familiar with the days with Internet. }\end{array}$ \\
\hline $\begin{array}{l}\text { 9. An advantage of online communication is that it can } \\
\text { remindevery group member to keep pace with others } \\
\text { at any moment. }\end{array}$ & $\begin{array}{l}\text { About } 85 \% \text { of the students agree with this opinion in } \\
\text { different level, they have got used to the life with } \\
\text { Internet by which they can deal with the most } \\
\text { questions. }\end{array}$ \\
\hline
\end{tabular}




\section{Conclusion}

We need to involve students in thinking dependently the whole process of the language learning. The teaching activity should create opportunities for students to try out different skills and interaction and negotiation through group work. By encouraging students to learn from other classmates and authentic tasks, we are helping them to consider for themselves what leads to their success and failure in language using. They should make better decisions about how to improve their language using practice. Hence, the teacher is not only source of information any more, but acts as facilitator so that students can actively interpret and organize the information they are given, fitting it into prior knowledge. The teachers should seek new ways to create an effective environment for language learners to learn. Combining the task-based approach with the college English teaching under the Internet-assisted multimedia environment, we can find that the language learners, the cognitive key role in the learning activity, have exerted their power sufficiently. Considering the multimedia as the cognitive tool, the language learners could take part in the teaching communicative activity actively and positively; they can look for, find and understand the knowledge by themselves; what's more, they can even grasp and apply what they had learnt to practice and become explorers and creators of language rather than passive recipients of it.

\section{References}

[1] N.S. Prabhu, Second language pedagogy. Oxford: Oxford University Press, 1987

[2] M. H. Long, Crookes, A role for instruction in second language acquisition: Task-based language teaching. Clevedon: Multilingual Matters, 1985, pp.77-99.

[3] D. Nunan, Designing Tasks for a Communicative Room. Cambridge: Cambridge University Press, 1989, pp. 56.

[4] J. A. Willis, Framework for Task-based Learning. London: Longman, 1996.

[5] J. C. Richards, The context of language teaching. Beijing: Foreign Language Teaching \& Research Press, 2000

[6] M. Breen, Learner contributions to task design. NJ: Prentice-Hall, 1987.

[7] L. Vygotsky, Thought and Language. Cambridge, MA: MTT Press, 1962

[8] P. Wilkins, Notional syllabus . Oxford: Oxford University Press, 1976

[9] G. Crookes and S. Gass, Tasks and Language Learning: Integrating Theory and Practice. Clevedon: Multilingual Matters, 1993.

[10] M. Warschauer and D. Healey, Computers and language learning: An overview . Language Teaching, vol 31, pp. 57-71, 1998

[11]Debski. Beyond the screen: Situating technology-mediated language learning .ON-CALL, vol 2, pp. 27-33, November 1997

[12] Xia Jimei and Kongxian. Comparison Between The Models And The Theoretical Bases Of Problem Solving Method And Task-Based Teaching Method, Foreign Language World, August 1998. (in Chinese)

[13] Zhang Chunxing, Educational Psychology, Hangzhou: Zhejiang Educational Press,1998. (in Chinese)

[14] Cheng Kela. A Study of Task-based Approach in Foreign Language Learning on Technology, Media in Foreign Language Instruction, pp.10-1, June 2003. (in Chinese) 